\title{
Growth, maturity and flowering of pigeon peas, Cajanus cajan L. Millsp., at high latitudes'
}

\author{
Rubén Vélez-Colón and Stephen A. Garrison ${ }^{z}$
}

\begin{abstract}
The effects of temperature and planting dates on germination, emergence, growth, vegetative development, and time to flowering and maturity of the pods of pigeon pea were evaluated. Growth chamber studies were conducted to determine the effects of $12.5^{\circ}, 15^{\circ}$, and $20^{\circ} \mathrm{C}$ on the germination of pigeon pea cultivar 2B-Bushy. Germination percentage was low $(1.0$ and $2.0 \%)$ at $15^{\circ}$ and $12.5^{\circ} \mathrm{C}$, respectively. At $17.5^{\circ}$, germination increased to $18 \%$ (average) and required 4 to 9 days. At $20^{\circ} \mathrm{C}$, germination was $48^{\circ}$ (average) and required 2 to 5 days. The vigor of the seed lot appeared to be low. Replicated field studies were conducted with large plant populations to determine the effect of planting date on emergence, growth, flowering and maturity of the pods of the commercial cultivar 2B-Bushy and two lines (PR2 7/13 and PR2 7/16) for early maturity in New Jersey (40 $\mathrm{N}$ lat.). Pigeon peas seeded May 19 emerged in 12 days at a mean soil temperature of $19^{\circ} \mathrm{C}$ at 2.5-cm depth. At later planting dates (2 June, 16 June, 1 July and 14 July) pigeon peas emerged in 6 or 7 days. Plant height and height to the first branch at flowering decreased in all three genotypes at the later planting dates. Pigeon peas planted at all sowing dates were tall but could be harvested with mechanical equipment. Planting date had a significant effect on the earliness of flowering and the percentage of plants that flowered. All plants of the PR2 selections flowered at all planting dates. The 2B-Bushy cultivar flowered only the first three planting dates; and not all the plants flowered. The 2B-Bushy flowered in the upper one-third of the plant, whereas the PR2 lines flowered in the upper two thirds. None of the plants of the 2B-Bushy genotype produced pods by the termination of the experiment, 15 October, just before frost. The PR2 lines seeded May 19 and June 2 produced $12 \%$ of the plants with mature green pods, and $6 \%$ of the plants with some dry pods, respectively, by 15 October. About 3\% of these PR2 plants had $90 \%$ of their pods dry by 15 October. Thus, the PR2 lines were highly variable for maturity at $40^{\circ} \mathrm{N}$ lat. Therefore, pigeon peas could be selected for adaptation to this location and even more northerly areas.
\end{abstract}

\section{RESUMEN}

\section{Crecimiento y floración del gandul, Cajanus cajan}

L. Millsp., en zonas templadas

Tres pruebas básicas se realizaron en esta investigación: efecto de la temperatura en la germinación de las semillas de gandul en condiciones reguladas; efecto de la temperatura en la germinación en condiciones de

' Manuscript submitted to Editorial Board 11 October 1988.

${ }^{2}$ Assistant Researcher, Agricultural Experiment Station, College of Agricultural Seiences, University of Puerto Rico, Río Piedras, P.R. and Associate Researcher, Rutgers, the State University of New Jersey. 
campo; y efecto de la fecha de siembra y el genotipo en el desarrollo vegetativo, tiempo a maduración y madurez de las vainas.

En condiciones reguladas, se requirieron de 2 a 5 días a $20^{\circ} \mathrm{C}$. para que la germinación ocurriera. La temperatura constante más baja a la que hubo un porcentaje significativo de germinación en un períado de tiempo aceptable (4 a 9 dias) fue $17.5^{\circ} \mathrm{C}$. Hubo germinación a $12.5^{\circ} \mathrm{C}$, pero fue en extremo baja y tardía.

En condiciones de campo, una temperatura media del suelo de $19^{\circ} \mathrm{C}$. (primera fecha de siembra, el 19 de mayo) produjo un porcentaje de brotación satisfactoria, pero estuvo significativamente por debajo del de las otras fechas de siembra, y requirió más tiempo (12 días). Las temperaturas medias del suelo para las otras fechas de siembra (2 de junio, 16 de junio, 1 de julio y 14 de julio) fueron $22^{\circ} \mathrm{C}$. o más. Las plantitas emergieron en 6 ó 7 días en estas condiciones.

Las plantas más altas al momento de la floración se obtuvieron de las semillas sembradas en la primera fecha. El tamaño disminuyó con las fechas de siembra más tardías. Las plantas de la última fecha de siembra (las que florecieron antes de que el experimento concluyera) requirieron el menor tiempo para florecer. El tiempo de la siembra a la floración disminuyó en las fechas de siembras más tardías.

El tamaño de la planta y el tiempo para florecer también estuvieron afectados significativamente por los genotipos. 2B-Bushy fue usualmente el más alto y consistentemente el más tardío con relación a la floración. PR2 $7 / 16$ mostró consistentemente el porte más bajo, excepto en la quinta fecha de siembra, mientras que PR2 7/13 fue consistentemente el que más temprano floreció.

\section{INTRODUCTION}

During the summer of 1983, a series of experiments were conducted at New Brunswick, New Jersey, U.S.A., to determine the adaptability of pigeon peas, Cajanus cajan L. Millsp. to local conditions. Specifically, the objectives were to evaluate the effects of low temperatures on seed germination under controlled conditions, and to determine the influence of planting date on seedling emergence, growth, vegetative development, time of flowering and maturity of the pods under field conditions.

The rationale that led to this investigation was the demand for pigeon peas among the large population of Puerto Ricans, Dominicans, and other West Indians in the states of New York and New Jersey. Large quantities of pigeon peas are imported from the Dominican Republic every year by the Goya Company. This company is established at Seacaucus, New Jersey. It is possible, in the long run, to develop lines able to germinate, emerge, grow, flower and produce from May or June to September or October at this latitude. A pigeon pea enterprise is economically feasible because it would have a sure market.

One of the main obstacles, however, is the known photosensitivity of pigeon peas $(1,2,6,7,9,10,12)$, which usually flower during short days. In New Jersey, as part of this study, some individual plants were observed to flower as early as 19 August (13 hours and 38 minutes of light); that is, less than 60 days after the longest day of the year (June 21). These precocious plants were selected and propagated, and might be reselected in successive years. 


\section{MATERIALS AND METHODS}

In order to quantify in the best possible manner the effect of low temperatures on germination, we conducted controlled trials at $12.5^{\circ} \mathrm{C}$ $\left(54.5^{\circ} \mathrm{F}\right), 15^{\circ} \mathrm{C}\left(59^{\circ} \mathrm{F}\right), 17.5^{\circ} \mathrm{C}\left(63.5^{\circ} \mathrm{F}\right)$ and $20^{\circ} \mathrm{C}\left(68^{\circ} \mathrm{F}\right)$. One hundred seeds of the variety 2B-Bushy, developed in Puerto Rico, were used for each temperature regime. Each Petri dish contained 25 seeds. We used 16 Petri dishes and 400 seeds.

The sterilized Petri dishes containing the seeds, $10 \mathrm{ml}$ of water and one sterilized blotter paper were placed inside plastic bags, on top of a damp paper towel. The plastic bags were then tied and placed in a growth chamber, in the dark. Observations were made daily.

The second part of the study consisted of field observations and measurements of the influence of planting date on seed emergence and plant growth and development.

A split-split plot design with four replications was used. Within each replication the five planting dates (main plots) were repeated randomly: 19 May, 2 June, 16 June, 1 July and 14 July. For each date, the three genotypes (subplots) were repeated randomly: 2B-Bushy, PR2 7/16 and PR2 7/13. The genotypes PR2 7/16 and PR2 7/13 are lines developed in New Jersey by Dr. Bernard L. Pollack, from seed collected in Puerto Rico and selected for early flowering. They are small with yellow flowers, light green pods and indeterminate. Once the seeds emerged, they were allowed to grow. We cultivated them as usual (herbicides Amiben $\mathrm{R}$ and Dacthal $R$, mechanical weeding and the insecticide Orthene $R$ ), up to flowering.

\section{RESULTS AND DISCUSSION}

At $20^{\circ} \mathrm{C}$, germination occurred for the first time the second day and continued up to the fifth day, for an average of $58 \%$ germination. At $17.5^{\circ}$ $\mathrm{C}$, germination occurred for the first time the fourth day and continued up to the ninth day, for an average of $28 \%$. At $15^{\circ}$ and $12.5^{\circ} \mathrm{C}$, germination was delayed and the percentage was low, and there was no growth after germination.

Because of these low percentages, the trials were repeated with exactly the same procedures. The second time, germination averages were even lower $\left(39 \%\right.$ at $20^{\circ}$ and $8 \%$ at $\left.17.5^{\circ}\right)$. Apparently, the seeds we used were low in vigor.

It seems logical to think that pigeon peas are subject to chilling injury, like so many other tropical and subtropical crops, such as cotton, maize, soybeans and peas $(3,4,5,8,11,13)$. As far as it is known, no trials have been conducted in relation to sensitivity to low temperatures in pigeon peas. The selection for good fast germination at low temperatures may be important for the adaptation of pigeon peas to temperate areas such as New Jersey. 
Seeds planted 19 May required 12 days to emerge under field conditions. It is presumed that this was due to the low temperatures, which averaged $19^{\circ} \mathrm{C}$ and went down to $9.5^{\circ} \mathrm{C}$, at $2.5-\mathrm{cm}$ depth. For the other four dates, emergence required only 6 or 7 days, as expected, and was significantly higher (table 1).

At time of flowering, measurements were taken of height of each flowered plant, as well as the height to the first branch. We recorded date of flowering and time elapsed before flowering. Using this information, we evaluated the effect of daylength on flowering as related to vegetative development.

Differences in the effect of daylength on flowering, as related to vegetative development, were statistically significant. The plants seeded 19 May grew to a height of $132 \mathrm{~cm}$ before flowering, 103 days later, and measured $17 \mathrm{~cm}$ up to the first branch. The plants seeded 2 June grew $129.7 \mathrm{~cm}$ before flowering, 90 days later, and measured $17.1 \mathrm{~cm}$ up to the first branch. On the other hand, the plants seeded 16 June grew 102.1 $\mathrm{cm}$ before flowering, 92 days later, and measured $10.3 \mathrm{~cm}$ up to the first branch. Finally, the plants seeded 1 and 14 July grew, respectively, 88 and $74.4 \mathrm{~cm}$ before flowering, 81 and 71 days later, and measured only 9.1 and $8.4 \mathrm{~cm}$ up to the first branch. These values are averages for the genotypes at the dates when the three of them flowered. At the dates when only the PR2 lines flowered, 1 and 14 July, the values are averages of these two genotypes.

PR2 7/13 was, at each date, the selection which required the least time to flower: 102 days for 19 May; 89 days for 2 June; 89 days for 16 June; 78 days for 1 July; and 69 days for 14 July. Cultivar 2B-Bushy, on the other hand, required much more time. In fact, many 2B-Bushy plants

TABLE 1.-Effect of planting date and genotype on emergence percentage and days to emergence

\begin{tabular}{lcc}
\hline $\begin{array}{l}\text { Date of } \\
\text { planting }\end{array}$ & $\begin{array}{l}\text { Percentage } \\
\text { emergence' }\end{array}$ & $\begin{array}{c}\text { Days to } \\
\text { emergence }\end{array}$ \\
\hline May 19 & $50.9 \mathrm{a}$ & 12 \\
June 2 & $76.4 \mathrm{~b}$ & 7 \\
June 16 & $75.5 \mathrm{~b}$ & 7 \\
July 1 & $75.8 \mathrm{~b}$ & 6 \\
July 14 & $76.6 \mathrm{~b}$ & 6 \\
Genotype & & - \\
PR2 7/16 & $80.1 \mathrm{a}$ & - \\
PR2 7/13 & $75.8 \mathrm{~b}$ & - \\
2B-Bushy & $57.3 \mathrm{c}$ & - \\
\hline
\end{tabular}

'The values in this column were obtained by dividing the number of seeds emerged in an individual row by the number of seeds used in that row, and then averaging those results per date and per genotype. Means followed by the same letter do not differ significantly at the 0.5 probability level with the Tukey (HSD) test. 


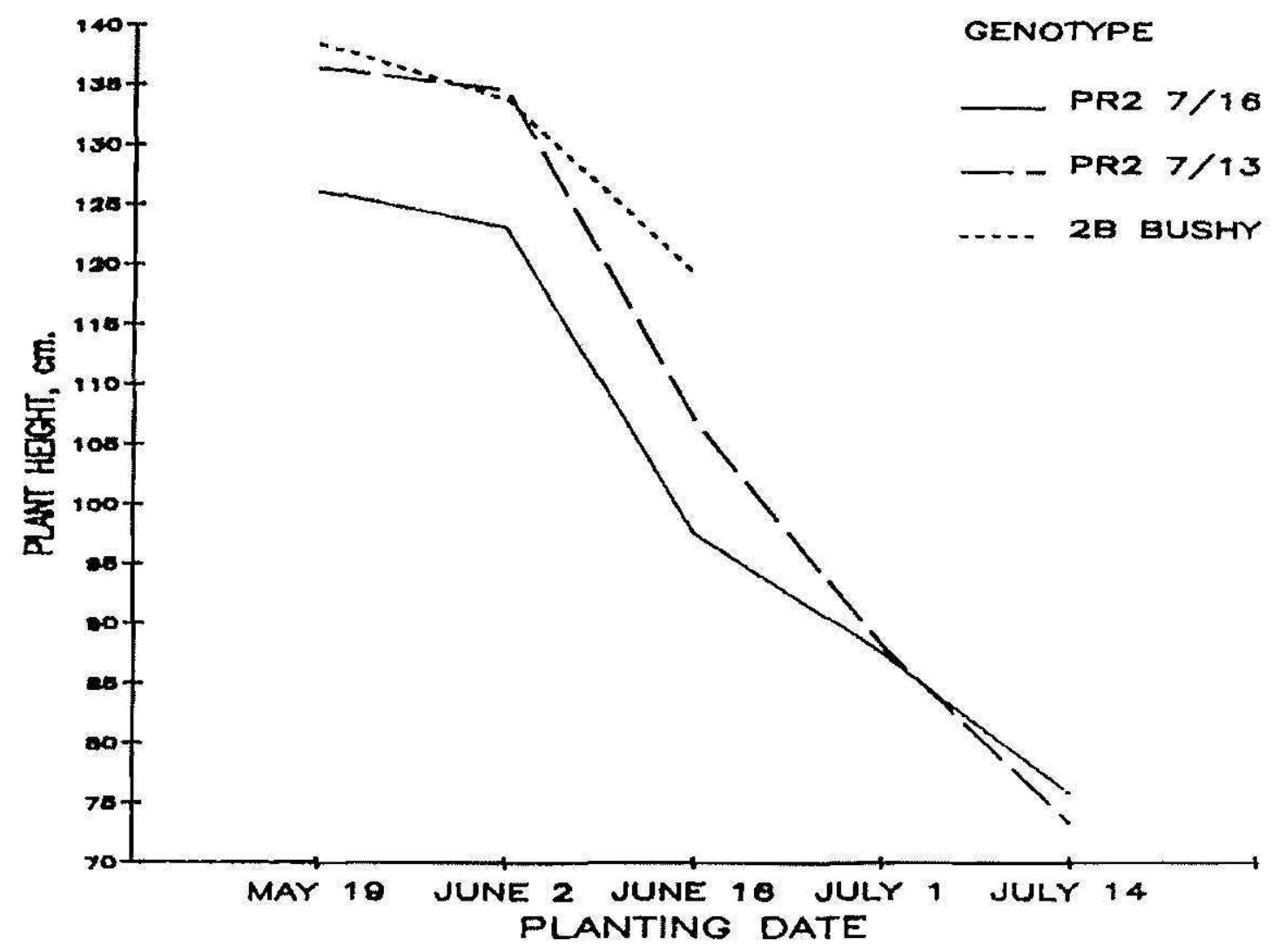

Fig. 1.-Effect of planting date and genotype on mean height of the plants at time of flowering.

at the first three dates did not flower. At the last two dates, none flowered before the termination of the experiment 15 October. Therefore, they were not taken into consideration for the statistical analyses (figures $1,2,3)$. The days required before flowering by $2 \mathrm{~B}$-Bushy were 132 for 19 May, 125 for 2 June and 106 for 16 June. PR2 7/16 required 104 days before flowering when seeded 19 May; 93 days when seeded 2 June; 95 days when seeded 16 June; 84 days when seeded 1 July; and 74 days when seeded 14 July.

\section{CONCLUSIONS}

Germination and emergence of pigeon peas are negatively affected by cool temperatures. The PR2 lines tested are capable of early flowering at lat. $40^{\circ} \mathrm{N}$. Some plants did produce a crop by the end of the growing season. Through breeding and selection, earlier flowering plants may be developed; thus a shorter growing season, with an increased yield, would free the land for a fall crop. For each of the genotypes tested, size of the plant at flowering is inversely related to time to flowering. Earlier flowering lines grew less. Individuals seeded late will grow less before flowering is initiated. 


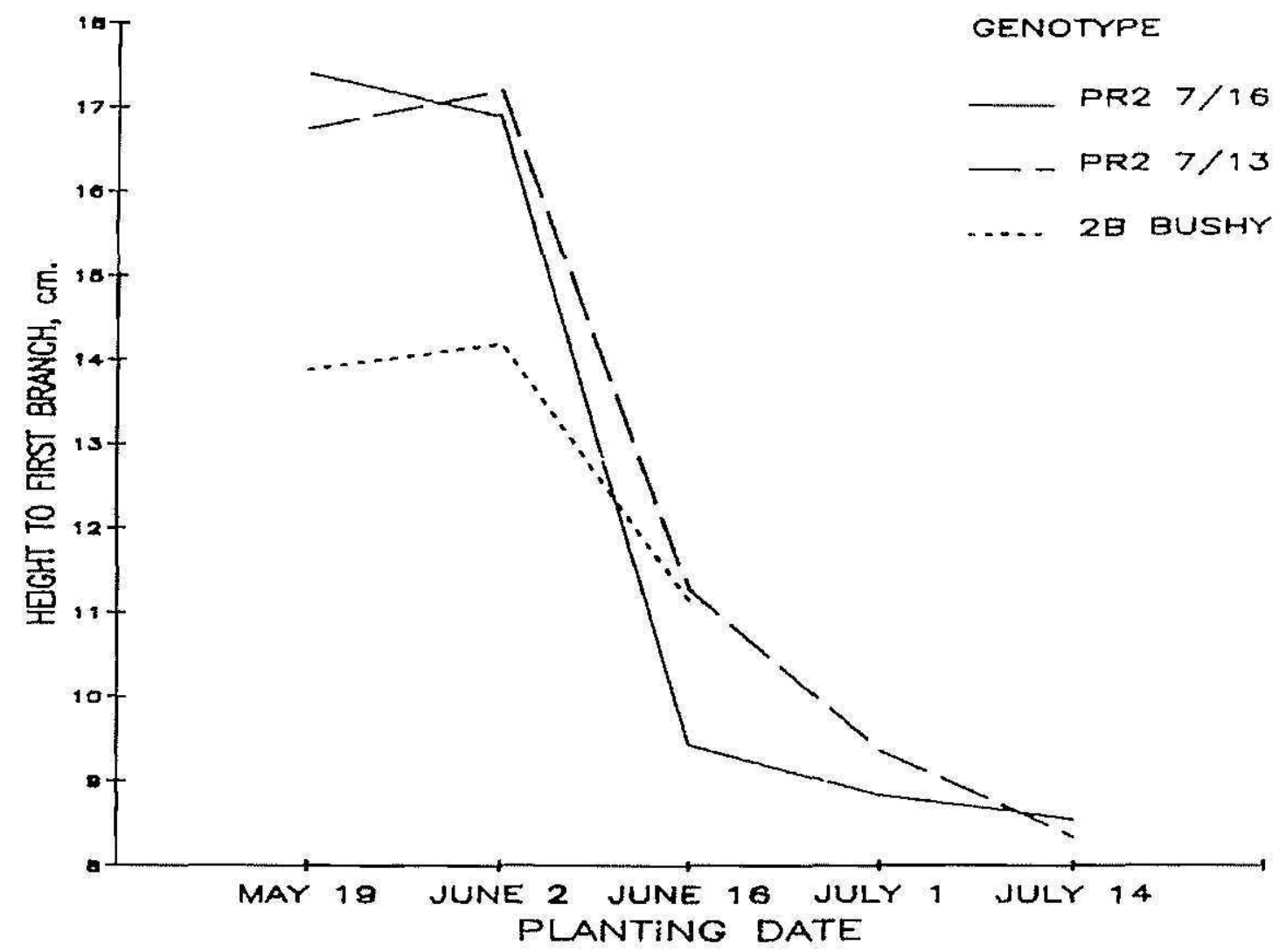

FIG. 2.-Effect of planting date and genotype on mean height to the first branch at time of flowering.

\section{LITERATURE CITED}

1. Abrams, R. and F. J. Juliá, 1973. Effect of planting time, plant population and row spacing on yield and other characteristics of pigeon peas, Cajanus cajan (L.) Millsp. J. Univ. P. R.: 275-84.

2. Akinola, J. O. and P. C. Whiteman, 1947a. Agronomic Studies on Pigeon Peas (Cajanus cajan (L.) Millsp.): Field Responses to Sowing Time. Aust. J. Agric. Res. 26: 43-56.

3. Bramlage, W. J., A. C. Leopold and D. J. Parish, 1978. Chilling Stress to Soybeans during Inhibition. Plant Physiol. 61: 525-29.

4. Christiansen, M. N., 1963. Influence of Chilling upon Seedling Development of Cutton. Plant Physiol. 38: 520-22.

5. Christiansen, M. N., 1967. Periods of Sensitivity to Chilling in Germinating Cotton. Plant Physiol. 42: 431-33.

6. Dahiya, B. S., J. S. Brar and J. N. Kaul, 1974. Changes in Growth Habit of Pigeon Peas (Cajanus cajan (L.) Millsp.) Due to Late Sowing. J. Agric. Sci. 83: 379-80.

7. Hammerton, J. L., 1976. Effects of Planting Date on Growth and Yield of Pigeon Peas. J. Agric. Sci. 87: 649-60.

8. Highkin, H. R. and A. Lang, 1966. Residual Effect of Germination Temperature on the Growth of Peas. Planta 68: 94-8.

9. Morton, J. F., R. Smith, M. A. Lugo-López and R. Abrams, 1982. Pigeon Peas (Cajanus cajan (L.) Millsp.: A Valuable Crop of the Tropics. Univ. P. R. Dep. Agron. Soils, under Contract AID/DSAN-G-0101 with the U.S. Agency for International Development.

10. Riollano, A., 1964. Effects of Photoperiodism and Other Factors on the Improvement of Pigeon Pea Varieties. J. Agric. Univ. P. R. 232-35. 


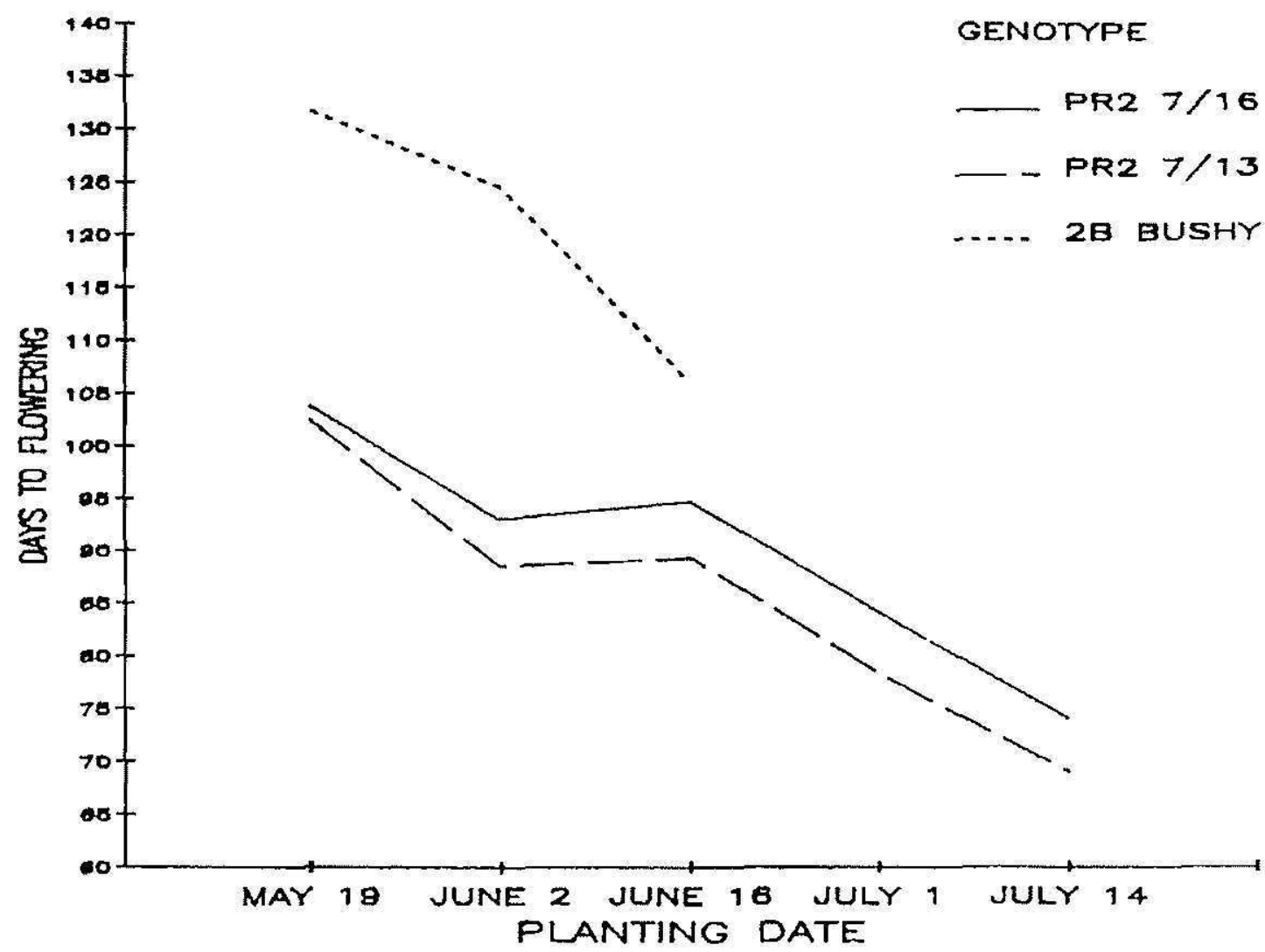

Fig. 3.-Effect of planting date and genotype on mean number of days from seeding to flowering.

11. Simon, E. W., 1980. Seed Germination at Low Temperatures. Low Temperature Stress in Crop Plants. 37-45.

12. Spence, J. A. and J. A. Williams, 1972. Use of Photoperiod Response to Change Plant Design. Crop Sci. 12: 121-22.

13. Thompson, P. A., 1970. Characterization of the Germination Response to Temperature of Species and Ecotypes. Nature 225: 827-31. 